\title{
Externalization of Border Controls as a Violation of Human Rights of Irregular Migrant Children: A Global Dilemma
}

\author{
Irekpitan Okukpon \\ Nigerian Institute of Advanced Legal Studies (NIALS), Yaba, Lagos State, Nigeria \\ Email: irekpitan.okukpon@gmail.com, i.okukpon@nials.edu.ng
}

How to cite this paper: Okukpon, I. (2020) Externalization of Border Controls as a Violation of Human Rights of Irregular Migrant Children: A Global Dilemma. Beijing Law Review, 11, 651-669.

https://doi.org/10.4236/blr.2020.113040

Received: April 27, 2020

Accepted: August 28, 2020

Published: August 31, 2020

Copyright $\odot 2020$ by author(s) and Scientific Research Publishing Inc. This work is licensed under the Creative Commons Attribution International License (CC BY 4.0).

http://creativecommons.org/licenses/by/4.0/

(c) (i) Open Access

\begin{abstract}
Various States have resorted to stringent border controls as irregular migrants sought to enter their territories within the past few years. These externalised border controls are sometimes, strictly enforced to the extent that irregular migrants-particularly vulnerable migrants such as unaccompanied minor children are arbitrarily detained in detention centres-the living conditions of which are in express violation of various international human rights treaties. This article examines the validity of these border controls which continue to negate the human rights of these irregular migrant children, and the role which the international community plays in upholding these established human rights The article discusses the extent to which these externalized border controls are enforced in Australia and across the European Union in law and in practice. The article concludes by proffering recommendations which facilitate a global harmonised governance system for irregular migrant children.
\end{abstract}

\section{Keywords}

Border, Controls, Migration, Detention

\section{Introduction}

In recent times, countries that play host to irregular migrants have been concentrating their efforts and resources on attempts to halt the flow of irregular migration ${ }^{1}$. Irregular migration is carrying an increasing number of people across international boundaries, putting a strain on immigration and citizenship policies in countries around the world. Further complicating the issue is the realisa${ }^{1}$ Van Waas, Laura (2007) The Children of Irregular Migrants: A Stateless Generation. Netherlands Quarterly of Human Rights, 25, 437 at 458. 
tion that irregular migration involves more than just the individuals who choose or are forced to enter into or remain in a country irregularly. Thus, the future of the children of these individuals, who enter into and remain in the receiving State by force or irregularly, is uncertain ${ }^{2}$ (Van Waas, 2007). Although family separations have been common among almost all migrants at various historical periods, immigration regimes today (in the legislative and enforcement sides) keep families separated for longer and more uncertain periods of time. These longer and more uncertain separations have prompted an increase in the migration of unaccompanied children to reunite in receiving countries ${ }^{3}$ (Menjivar, 2006).

However, the subject of international debate in recent years is legality of externalization policies of receiving countries/destination states and the ways in which these policies negate the human rights of irregular migrant children. While states' sovereign power is not without limitations, including those imposed by international human rights law, migrants in an irregular situation find themselves in a legal vacuum, as the tension between these two structures remains unresolved ${ }^{4}$ (Cassese, 2001).

The precariousness of being undocumented arises from the particular role ascribed to States themselves as guardians or protectors of human rights and from a tendency to confine certain rights within a context of community or citizenship (Goodwin-Gill, 1989) . Bhabha observes that a large number of children could be said to be functionally stateless, whether or not they have a legal nationality. Despite not being stateless according to the current legal definition of the term ${ }^{6}$, the fact that they do not have the citizenship of the state they reside in places them in a particular legal void, an ambiguous position between inalienable and unenforceable rights ${ }^{7}$ (Bhabha, 2009). This condition of statelessness of children appears to entail a loss of the "right to have rights" or the person's recognition, by others, as a member of a given community.

Within the past few years, the detention of irregular migrants and accompanying children as a form of control by destination States to control who enters or remains within their territories has been a major course of concern. Whilst the act of detention is not a crime in itself, it is the treatment of children and their families in such a manner that it emphasizes their statelessness and the infringe${ }^{2}$ Van Waas, ibid.

${ }^{3}$ Menjivar, C. (2006) Liminal legality: Salvadoran and Guatemalan immigrants' lives in the United States.) Am. J. Sociol. 111 (4), 999-1037; Mejivar, Cecilia (2014) Immigration Law Beyond Borders: Externalizing and Internalizing Border Controls in an Era of Securitization' Annu. Rev. Law. Soc. Sci 10,353 at 361 .

${ }^{4}$ Cassese, A. (2001) International Law, Oxford: Oxford University Press, 97.

${ }^{5}$ Goodwin-Gill, G. (1989) International Law and Human Rights: Trends Concerning International Migrants and Refugees', International Migration Review, 23, 526.

${ }^{6}$ According to the UN Convention Relating to the Status of Stateless Persons, the term refers to "a person who is not considered as a national by any State tinder the operation of its law". Convention Relating to the Status of Stateless Persons (adopted 28 September 1954, entered into force 6June 1960) 360 UNTS 117; Article i(i).

${ }^{7}$ Bhabha, J. (2009) Arendt's Children: Do Today's Migrant Children Have a Right to Have Rights? Human Rights Quarterly 31, 410, 412. 
ment on their fundamental human rights that constitute an international and national problem.

This article examines the role of the international community in enforcing the rights of irregular migrant children in the $21^{\text {st }}$ century. Part 1 provides a background and introduction to the paper. Part 2 discusses the factors which necessitate international migration and the roles of states in adopting externalization policies to curtail irregular migrant children. Part 3 provides an expose on the protections afforded by irregular migrant children under existing international human rights instruments. Part 4 analyses the legality of externalization policies in specific jurisdictions and how these policies provide effective protection of the rights of irregular migrant children. Part 5 discusses the role of the European Court of Human Rights regarding enforcement of the rights of irregular migrant children. Part 6 proffers recommendations towards protection of the human rights of irregular migrant children Part 7 concludes the paper. This article utilises a socio-legal approach in its analysis, with reference to documents which employed credible qualitative and quantitative data, in order to provide a detailed overview of the topic.

\section{International Migration and Externalization Policies}

An undocumented or irregular migrant is described by the 1990 International Convention on the Protection of the Rights of All Migrant Workers and Members of their Families as any person without a permit authorising them to enter, to stay or to engage in a remunerated activity in the State of destination pursuant to the law of that State and to international agreements to which it is a Party ${ }^{8}$ (UN Committee, 2012).

Migration across borders is an archetypical transnational phenomenon ${ }^{9}$ (Estrada-Tanck, 2013). The causes of migration are complex and myriad and result in no small measure from the phenomenon of globalization in the economic, political and cultural spheres. Factors including demographic and skills deficits in much of the industrialised world, insufficient employment, armed conflicts, etc. indicate that migration is both necessary and here to stay ${ }^{10}$ (Fraser \& Konigs, 2012).

Migration is an important economic and social phenomenon, with States having the sovereign right to determine their migration policies. However, this right to determine their migration policies is constrained by the obligations ${ }^{8}$ Based on Article 5 of the UN Convention on Migrant Workers and adapted to cover not only migrant workers but migrant persons in general; UN Committee on Rights of Migrant Workers, Draft General Comment No. 2 on the rights of migrant workers in an irregular situation and members of their families, December 2012, point 1.3 (last checked 01 February 2020) http://www2.ohchr.org/english/bodies/cmw/GC2.htm.

${ }^{9}$ Estrada-Tanck, Dorothy (2013) Human Security and the Human Rights of Undocumented Migrants: Systemic Vulnerabilities and Obligations of Protection. European Journal of Social Security $15,155$.

${ }^{10}$ Fraser, Juliet and Konigs Tomas (2012) Towards the Benefit of All: Protecting Migrants' Rights in a Globalised World. Merkorious-Utrecht Journal of International and European Law 28 (75), 55 at 66. 
voluntarily assumed by States under international human rights law, as well as customary law, including the obligation of non-refoulement i.e. the removal or return of anyone to a country where they would be at risk of persecution torture or other serious human rights violations ${ }^{11}$ (Migration \& Human Rights). Within this sovereign right of States to determine migration policies, some States shift the responsibility for providing international protection to refugees and asylum-seekers to other countries, or the enlistment of source or transit countries to tighten control over their borders. Such externalization policies of destination state include "push-backs" by land or sea, involving automatically pushing back people who are attempting to cross a border towards a country from which they came. They are unlawful because they take place without procedural safeguards and without respecting the right of individuals to challenge their expulsion or apply for asylum. Transit states also have pushbacks and "pull-backs" i.e. preventing people from leaving. These are also unlawful because they take place without procedural safeguards and without respecting the right of individuals to leave any country, including their own ${ }^{12}$ (Amnesty International, 2017).

Accordingly, these externalizations may actually trigger, directly or indirectly, one or more categories of rights violations. Regardless of their status or location, migrants have a range of fundamental rights that can be implicated by migration-control externalization practices and which protect migrants against abuse throughout the migration process ${ }^{13}$ (Frelick, Kysel, \& Podkul, 2016). The extent of the implication of these externalization practices on the fundamental rights of irregular migrant children is what this article focuses on.

Migrating children and youth-whether between or within countries and whether accompanied by their relatives or not-have become a recognised part of today's global and mixed migration flows ${ }^{14}$ (Fraser \& Konigs, 2012). Children can migrate in various ways. Children move across borders with their parents or are accompanied by extended family members or other adults and within mixed migratory flows. Children are also increasingly seeking migration opportunities to move across borders autonomously and unaccompanied. Falling prey to transnational organized crime and exploitation practices including smuggling, trafficking in persons and contemporary forms of slavery, which are described as abusive forms of migration, may also be a part of the migration experience for many children. Migration potentially enhances the child's opportunities and future choices. However, many forms of migration, like the treatment of children during the migration process, can also pose serious threats to the child's rights. The potential

${ }^{11}$ United Nations Human Rights. Migration and Human Rights-Improving Governance of International Migration, 8, 16 (last checked 01 February 2020)

https://www.ohchr.org/Documents/Issues/Migration/MigrationHR_improvingHR_Report.pdf.

${ }^{12}$ Amnesty International (2017) The Human Rights Risks of External Migration Policies. Amnesty International Ltd: London, 5.

${ }^{13}$ Frelick, Bill, Kysel M Ian \& Podkul, Jennifer (2016) The Impact of Externalization of Migration Controls on the Rights of Asylum Seekers and other Migrants. Journal on Migration and Human Security, 4 (4), 190 at 197.

${ }^{14}$ Fraser \& Konigs (n 10) 75. 
benefits of migration may be eroded for both undocumented children and children with an irregular migration status, who are exposed to the denial of rights, such as arbitrary deprivation of liberty and limited or no access to health-care services and education ${ }^{15}$ (Migration, Human Rights \& Governance, 2015).

The transnational nature of migration however poses a problem as to the best way to meet the human rights obligations of such migrant persons based on the universal paradigm guiding human rights principles. This principle holds that all persons are equal in dignity and rights and should therefore not be discriminated against on the basis of culture, language, ethnicity or national rights among other attributes. However, the universality of human rights may be doubtful when applied to the case of migrant children ${ }^{16}$ (Estrada-Tanck, 2013). Thus, the role of international human rights law is examined to determine the extent to which it contributes to the protection of irregular migrant children.

\section{International Human Rights Instruments and Protection of Irregular Migrants, including Children}

The rights of all migrants receive comprehensive elaboration and thus, protection only indirectly - by application of general human rights treaties (which recognize that all human beings have rights) or by virtue of treaties which protect sub-groups of migrants, such as refugees or migrant laborers ${ }^{17}$ (Kysel, 2016). Human rights law asserts equality of treatment between citizens and non-citizens in accordance with the national standard ${ }^{18}$ (Chetail, 2013).

Amador aptly states:

... International law today recognizes that individuals and other subjects are directly entitled to international rights just as it places upon them certain international obligations ... the basis of this new principle would be the "universal respect for, and observance of, human rights and fundamental freedoms" referred to in the Charter of the United Nations and in other general, regional and bilateral instruments. The object of the "internationalization" ... of these rights and freedoms is to ensure the protection of the legitimate interests of the human person, irrespective of his nationality. Whether the person concerned is a citizen or an alien is then immaterial: human beings, as such, are under the direct protection of international law. (Amador, 1956) ${ }^{19}$.

\footnotetext{
${ }^{15}$ Migration, Human Rights and Governance-Handbook for Parliamentarians No 24. (2015) Inter-Parliamentary Union/International Labour Organization/The United Nations (Office of the High Commissioner for Human Rights, 113 (last checked 10 February 2020)

https://www.refworld.org/docid/57b6e1697.html.

${ }^{16}$ Estrada-Tanck (n 9), 156.

${ }^{17} \mathrm{Kysel}, \mathrm{M}$ Ian (2016) Promoting the Recognition and Protection of the Rights of All Migrants using a Soft-Law International Migrants Bill of Rights. Journal of Migration and Human Security, 4 (2), 29 at 31; Frelick et al. (n 13) 197.

${ }^{18}$ Chetail, Vincent (2013) The Human Rights of Migrants in General International Law: From Minimum Standards to Fundamental Rights' Georgetown Immigration Law Journal, 28, 231-2.

${ }^{19}$ Special Rapporteur F V Garcia Amador's International Responsibility (1956) 2. Y B Int'l L Comm'n 173 at $184,192,1193$.
} 
From a general international law perspective, the rights of non-citizens have bee (re)discovered quite recently as a side effect of the normative expansion of the international human rights law. The Universal Declaration of Human Rights, the UN International Covenant on Civil and Political Rights (ICCPR) and the UN International Covenant on Economic and Social Rights proclaim in their preamble "the recognition of the inherent dignity and of the equal and inalienable rights of all members of the human family ${ }^{20}$ (ICCPR \& ICESR, 1966). The United Nations General Assembly adopted in December 1985, the Declaration on the Human Rights of Individuals who are not Nationals of the Country in which they live $e^{21}$ (UN Resolution, 1985). Indeed, the ICESR contains specific provisions regarding the state obligation to reduce infant mortality and ensure healthy child development ${ }^{22}$ (ICESR, 1966); protection of children from economic and social exploitation ${ }^{23}$ and the right to education ${ }^{24}$. In 1990, the UN adopted a specific convention on migrant workers i.e. the International Convention on the Protection of the Rights of all Migrant Workers and Members of their Families (ICRMW $)^{25}$. The ICRMW applies during the entire migration process of migrant workers and members of their families, which comprises preparation for migration, departure, transit and the entire period of stay and remunerated activity in the State of employment... ${ }^{26}$ The ICRMW obligates States Parties to pay particular attention to the problems that may be posed to minor children by the deprivation of a migrant worker's liberty ${ }^{27}$. The Convention also addresses the basic rights of all migrant workers to "access ... education on the basis of equality of treatment with nationals of the State concerned" with "access to public pre-school educational institutions or schools ... not [to] be refused or limited by reason of the irregular situation with respect to stay of employment of either parent or by reason of the irregularity of the child's stay in the State of employment" ${ }^{\prime 2}$. Although these provisions obligate State Parties to facilitate the attainment of these rights, the Convention envisages such facilitation where either parent of the child is a legal migrant worker, and not in circumstances where the migrant is illegal/irregular/undocumented.

${ }^{20}$ Preamble, Para 1 of the ICCPR 1966 and the ICESR 1966.

${ }^{21}$ G.A. Res. 40/14, U.N. Doc. A/RES/40/144 (Dec. 13, 1985).

${ }^{22}$ Article 12 (2) (a) ICESR.

${ }^{23}$ Article 10 (3) ICESR.

${ }^{24}$ Article 13.

${ }^{25}$ This Convention recorded a slow number of ratification and only entered into force in July 2003, 13 years after its adoption. At the universal level, multilateral treaties specifically adopted focus on three main categories of migrants. They include the 1951 Convention Relating to the Status of Refugees which governs refugees generally; the 1948 Convention Concerning Migration for Employment (Revised) (No. 97); 24 the 1975 Convention Concerning Migrations in Abusive Conditions and the Promotion of Equality of Opportunity and Treatment of Migrant Workers (No. 143), and the 1990 International Convention on the Protection of the Rights of All Migrant Workers and Members of their Families (ICRMW); 2000 Protocol against the Smuggling of Migrants by Land, Sea and Air and the Protocol to Prevent, Suppress and Punish Trafficking in Persons, Especially Women and Children Supplementing the United Nations Convention against Transnational Organized Crime i.e. for smuggled and trafficked migrants.

${ }^{26}$ Article 1 (2) ICRMW.

${ }^{27}$ Article 17 (6).

${ }^{28}$ Article 30; Migration, Human Rights and Governance (n 15) 114. 
As such, the Convention caters mainly for migrant workers and is not applicable to "refugees and stateless persons, unless such application is provided for in the relevant national legislation of or international instruments in force for, the State Party concerned"29 (ICRMW, 1990). This clause already disqualifies irregular migrants and their children from the benefits accorded to regular migrant workers under the Convention. The low rate of ratification of this Convention speaks to the fact that the international community is not satisfied with the inadequate protection afforded migrants under this treaty and the protection of irregular migrant children. Currently, there appears to be no single international instrument that clearly and explicitly enshrines the protection of a core baseline of rights (and corresponding set of minimum state obligations) and applies to all migrants regardless of the cause of their migration ${ }^{30}$ (Kysel, 2016).

However, with respect to the express protection of the rights of migrant children, the Convention on the Rights of the Child (CRC) 2003 is mostly relied on in international law. Article 2 of the CRC obligates State Parties to respect and ensure the rights of each child within their jurisdiction without discrimination of any kind, irrespective of the child's or his/her parents race, colour, sex, nationality or other status. Accordingly, State Parties are to take all appropriate measures to ensure that the child is protected against all forms of discrimination or punishment on the basis of the status, activities, expressed opinions or beliefs of the child's parents, legal guardians or family members (Child Rights Act) ${ }^{31}$. Whilst these provisions provide a footing for irregular migrant children, certain questions arise from these provisions of the CRC in relation to the human rights of irregular migrant children. Noll puts forward the argument that if undocumented/irregular migrants are physically present in the territory of a destination state, they come under its jurisdiction and their jurisdictional presence triggers human rights obligations. However, what is that State obliged to do or not do in relation to such a migrant, particularly where such a person is not yet a member of the political community? $?^{32}$ (Noll, 2010). This quandary arising from the failure of existing international instruments to provide an over-arching instrument protecting the human rights of irregular migrants and their children has led to constant violations of human rights of these categories of persons by States exercising their sovereign power to protect its borders from them. These externalization policies, specifically the detention of migrant children, emphasize the degradation of the human rights of these migrant children. The International Organisation on Migration (IOM) defines detention of migrants, whether criminal or administrative, as the "restriction on freedom of movement through confinement that is ordered by an administrative or judicial authority"33 (IOM, 2011). The sub${ }^{29}$ Article 3 (d), ICRMW.

${ }^{30}$ Kysel (n 22) 31.

${ }^{31}$ Article 2 (1) and (2), Child Rights Act.

${ }^{32}$ See generally, Noll, Gregor (2010). Why Human Rights Fail to Protect Undocumented Migrants. European Journal of Migration and Law, 12, 241 at 249-254.

${ }^{33}$ International Organisation for Migration (2011). Appendix B-IML Information Note on International Standards on Immigration Detention and Non-Custodial Measures. IOM Submission to the Working Group on Arbitrary Detention, 2. 
sequent parts of this paper examines the veracity of this statement, the role of international law as a blanket to cushion the effects of these policies imposed by States and the role of States in restricting or promoting these freedoms.

\section{Externalization Policies: Eroding the Human Rights of Migrant Children or an Enforcement of Sovereign Rights of States?}

Scenes of irregular migrants stranded at the southern borders of the European Union (EU) and the United States (US) have permeated social media in the last few years ${ }^{34}$ (Johnson, 2015). Whilst States are within their rights to adopt externalized border controls which allow governments to detain non-citizens for migration-related reasons, concerns have been raised regarding the arbitrary and unlawful detention of these irregular migrants in overcrowded and unhygienic conditions falling below international standards, some of which amount to human rights violations ${ }^{35}$ (Mossou, 2017). Of particular concern is the exposure of children as an extremely vulnerable group, to detention and its harmful consequences $^{36}$ (Mossou, 2017), particularly where they are unaccompanied ${ }^{37}$ (Parkin, 2015). This part of the article discusses incidents of arbitrary detention in Australia and across Europe, and how the courts and international law have addressed these human rights violations. It is important to note that this paper considers these two continents to highlight the marked differences in their legal and political approaches to detention of irregular migrant children.

\subsection{Detention of Irregular Migrant Children in Australia}

This article discusses the Australian system of detention because of the controversy which has trailed this jurisdiction and its immigration policies within the past few years. Australia's system of mandatory immigration detention was introduced by the Labor Government in 1992. Its Migration Act refers to unlawful non-citizens as people who have arrived in Australia without a visa or have arrived in Australia with a visa that has later expired. If unlawful non-citizens arrive in Australia by sea, they are referred to as "unauthorised maritime arrivals". Hence, unlawful non-citizens (including unauthorised maritime arrivals) who are detained may only be released from immigration detention if they are granted a visa, if they are moved into Community Detention or if they are being removed from Australia ${ }^{38}$ (Australian Human Rights Commission, 2014).

Nevertheless, Australia's migration policy requirements are to detain irregular

${ }^{34}$ Johnson, Nicole (2015). Deterrence, Detention and Deportation: Child Migrants in the United States \& the European Union. Heinrich Boll Stiftung: Washington DC, III.

${ }^{35}$ Mossou, Sylvain (2017). Child Immigration Detention in Europe-Human Rights Programme Report. Quaker Council for European Affairs: Belgium, 6.

${ }^{36}$ Mossou, ibid.

${ }^{37}$ For example, in 2014, half of the child migrants entering Italy were unaccompanied, and as at 2015, two-thirds of child migrants entering the EU were unaccompanied. Parkin, Gemma (2015). The EU can no longer stand by while child migrants are drowning. The Guardian, April 21; Johnson (n 34) IV.

${ }^{38}$ The Forgotten Children-National Inquiry into Children in Immigration Detention (2014). Australian Human Rights Commission: Sydney, 24. 
migrants on arrival in Australia and transfer children who are unauthorised maritime arrivals to a Regional Processing Country. Officers are required by the Migration Act to carry out these tasks, regardless of whether it would be in the child's best interests $^{39}$ (Australian Human Rights Commission, 2014). Despite the fact that section 4AA of the Migration Act explicitly stating that "a minor shall only be detained as a measure of last resort", the detention of migrant children is the first action of the Australian government. These are in outright disregard of the provisions of the Convention on the Rights of the Child which provides that "if detention of children is necessary in order to achieve a particular aim, then the length of detention should be the shortest appropriate period for the achievement of that aim". The Convention also requires that "children in detention should be treated with humanity and respect" and "should not suffer torture or cruel, inhuman or degrading treatment or punishment”.

Australian detention centres for irregular migrants in Nauru and Christmas Island are cramped enabling rapid spread of infections. The children and their families live in converted shipping containers, the majority of which are $3 \times 2.5$ metres. Children are effectively confined to these rooms for many hours of the day as they are the only private spaces which provide respite from the heat. From 2013 to 2014, families in the detention centres shared common bathroom facilities with everyone else at the centres, and detained children had no access to school education for the period stated. As the Christmas Island detention centre is located in carved out sections of the tropical rain forest, the fences of the detention centres do not keep out the crabs, giant centipedes and wild chickens which are prolific to that centre ${ }^{40}$ (Australian Human Rights Commission, 2014) which regularly bite and constitute grave danger to children and their parents. An Inquiry carried out by the Australian Human Rights Commission provides a clear picture of what children thought about detention from interviews of children in detention facilities: “A feeling of darkness came on me in the detention centre, and all my hope disappeared ... It was like a desert. It felt like were in a cage. We could not go anywhere with all the fences and stuff ..." These combined factors facilitate a disruption in the normal development of children, damaging their emotional health and social development ${ }^{41}$ (Australian Human Rights Commission, 2004).

As such, detained migrant children at Christmas Island did not enjoy the right

\footnotetext{
${ }^{39}$ The Forgotten Children, ibid, 26.

${ }^{40}$ The Forgotten Children (n 38) 76, 107.

${ }^{41}$ These statements were culled from the following submissions to the Inquiry: Coalition for Justice for Refugees, Submission 73; ChilOut, Submission 120; National Legal Aid, Submission 171; Kids in Detention Story, Submission 196; Western Young People's Independent Network and Catholic Commission for Justice Development and Peace Melbourne, Submission 199; Youth Advocacy Centre and Queensland Program of Assistance to Survivors of Torture and Trauma, Submission 84, p 29. See generally Australia's Immigration Detention Policy and Practice-A last resort? National Inquiry into Children in Immigration Detention, Australian Human Rights Commission (last checked 10 June 2020) https://humanrights.gov.au/our-work/6-australias-immigration-detention-policy-and-practice.
} 
to the highest attainable standard of health ${ }^{42}$, or the right to a standard of living adequate for their physical, mental, spiritual, moral and social development ${ }^{43}$, or the right to be treated with humanity and respect for the inherent dignity of the human person, and in a manner which takes into account the needs of persons of his or her age ${ }^{44}$ (Convention on the Rights of the Child). These violations of the human rights of children by the Australian government received backlash by various international humanitarian organisations which led to Malaysia and Papua New Guinea's refusal in 2016 to allow Australia send irregular migrants to its territories for detention as it violated the Constitution and human rights legislation of both countries ${ }^{45}$ (Human Rights Watch, 2016). Although Australia still continues to maintain its sovereign right to detain irregular migrants under its laws, international human rights law remains a persistent check on the arbitrariness of the detention of these irregular migrant children in that jurisdiction.

\subsection{Detention of Irregular Migrant Children in Europe}

Immigration of children is also a growing phenomenon in Council of Europe member states ${ }^{46}$ (Parliamentary Assembly, 2014). The Council of Europe has recognized that many Member States are working to end detention of child migrants. For example, in Hungary, detention of migrant children is prohibited ${ }^{47}$. With the assistance of local non-governmental organizations, the government established a shelter for unaccompanied children ${ }^{48}$ (Parliamentary Assembly, 2014).

In Sweden, asylum seekers are registered upon arrival and after being issued an identity card and having spent about a week in transit they are moved into a reception programme. The authorities accommodate those who do not have their own funds to cover accommodation costs. As a rule, they are placed in a private apartment rented for them by the government. These migrant children are receiving the same medical care as Swedish children. Migrants are assigned a caseworker; they can receive free legal aid and participate in special courses of the Swedish language. They receive a daily allowance and in some cases they are even allowed to work $^{49}$ (Sampson \& Mitchell, 2013). In Italy, the law does not ${ }^{42}$ Article 24 (1), Convention on the Rights of the Child (CRC).

${ }^{43}$ Article 27 (1), CRC

${ }^{44}$ Article 37(c), CRC

${ }^{45}$ Human Rights Watch (2016) Papua New Guinea: Address Abuses at UN Review: Make Good on Commitment to Close Manus Detention Centre. Human Rights Watch: New York (last checked 15 February 2020)

https://webcache.googleusercontent.com/search?q=cache:AYNPj36NpxsJ:https://www.hrw.org/news /2016/05/04/papua-new-guinea-address-abuses-un-review $+\& \mathrm{~cd}=1 \& \mathrm{hl}=\mathrm{en} \& \mathrm{ct}=\mathrm{clnk} \& \mathrm{gl}=\mathrm{ng} ; \quad$ Frelick et al. (n 13) 206.

${ }^{46}$ Parliamentary Assembly (2014). The alternatives to immigration detention of children' Doc. 13597, 15 September, 6 (last checked 14 January 2020) http://assembly.coe.int/nw/xml/XRef/Xref-XML2HTML-en.asp?fileid=21130\&lang=en.

${ }^{47}$ Section $56 \mathrm{f}$ At II of 2007 on the Admissions and Rights of Residence of Third-Country Nationals. ${ }^{48}$ Parliamentary Assembly (n 46) 11.

${ }^{49}$ Sampson, Robin \& Mitchell, Grant. (2013) Global Trends in Immigration Detention and Alternatives to Detention: Practical, Political and Symbolic Rationales. Journal on Migration and Human Security, 3 (1), 035; Parliamentary Assembly (n 46) 12. 
prohibit the detention of children accompanied by parents in detention centres by migrants, but the detention of unaccompanied children in those centres is prohibited $^{50}$ (PICUM, 2012).

Most European countries' policies appear to leave open the possibility for detention, which is counter to emerging international human rights standards increasingly supporting a no-detention policy for children which is detrimental to their best interests. Consequently, there are reports from civil society organisations which suggest that in some countries, there is a gap between law and policy on one hand, and what happens in practice on the other ${ }^{51}$ (Mossou, 2017). For example, in Hungary where detention of migrant children appears to be prohibited, it is reported that when unaccompanied children apply for asylum and are aged over 14, they are transferred to the closed transit facilities at the border with Serbia where they are deprived of liberty ${ }^{52}$ (European Union Agency for Fundamental Rights Report, 2017). In Belgium, while the country has seemingly been able to limit the detention of accompanied children, there have been concerns from civil society organisations which have led to the creation of a campaign "We do not detain a child. Full stop" ${ }^{53}$ brings together 50 organisations against the government's late 2016 announcement to build a closed centre especially for families with children ${ }^{54}$ (Mossou, 2017). In France, the annual report on administrative detention in France published by six civil society organisations present in detention centres details the systematic use of deprivation of liberty as a primary instrument of migration control. The report underlines that 2016 reached a record in terms of the number of children detained in spite of condemnations by the European Court of Human Rights ${ }^{55}$ (Migreurop, 2014). 182 children were detained in mainland France and in one of the country's overseas territories, Mayotte, the number goes up to a dramatic 4, 2485 children detained $^{56}$ (Mossou, 2017).

These actions by European member states allude to the fact that they are determined to continue to enforce detention policies with regards to children and their families, despite its prohibitions by international human rights law in that regard. In view of this, the paper focuses on a discussion of the role played by European Court of Human Rights in facilitating the cessation of detention of

${ }^{50}$ PICUM Submission to the OHCHR Special Rapporteur on Migrants, Thematic Report on Detention (2012), 26 January, 4.

${ }^{51}$ Mossou (n 35) 13; Council of Europe (2014). The Alternatives to Immigration Detention of Children. September 15 (last checked 21 February 2020) https://www.refworld.org/pdfid/547c7c834.pdf

${ }^{52}$ European Union Agency for Fundamental Rights Report (2017). European legal and policy framework on immigration detention of children. 44; Mossou (n 35) 13.

${ }^{53}$ Coordination et Initiatives pour réfugiés et étrangers: Lancement de la campagne 'on n'enferme pas des enfants. Point (last checked 13 February 2020)

https://www.cire.be/presse/communiques-de-presse/lancement-de-la-campagne-on-n-enferme-pasun-enfant-point-communique-de-presse-14-juin-2016; Mossou (n 40) 13.

${ }^{54}$ Mossou (n 35) 13.

${ }^{55}$ The Hidden Face of Immigration Detention Camps in Europe (2014). Open Access Now, 42 (last checked 22 February 2020) http://www.migreurop.org/article2537.html?lang=fr; Mossou (n 40)13; Johnson (n 39) VIII.

${ }^{56}$ Mossou (n 35) 13. 
migrant children over the past few years.

\section{The Role of the European Court of Human Rights and Detention of Migrant Children}

The European Court of Human Rights (ECtHR) is considered as one of the most important institutions in Europe with regards to the settlement of international legal disputes. Therefore, the right to challenge the lawfulness of detention before a court is a well-established principle of customary international law ${ }^{57}$ (UN Human Rights Council, 2008), which an irregular migrant can rely on. Consequently, whilst the ECtHR has considered cases relating to the arbitrary detention of irregular migrants, it appeared to explicitly permit the detainment of irregular migrants for the purpose of enforcing migration control by virtue of its Article 5 (1) (f) "to prevent [a person] effecting an unauthorised entry into the country"58 (Chetail, 2014). Indeed, the ECtHR held in line with the UK House of Lords ${ }^{59}$ that detention of undocumented immigrants is "a necessary adjunct" to the "undeniable sovereign right to control aliens" entry" (Saadi v UK, 2008). Whilst these pronouncements of the ECtHR appear to be controversial and in blatant support of detention, its perspective on detention of irregular migrants appeared to change in successive years with landmark cases in the Beligum and French situations. Whilst there are numerous ECtHR cases from 2010 till present day which emphasize the ECtHR's outright condemnation of the practice of detaining irregular migrant children, the particular cases of Muskhadzhiyeva and Others v. Belgium, Kanagratam v Belgium and Popov v France are utilised in this article, particularly because of the Belgian and French practices of detaining migrant children in their territories as described above.

The case of Muskhadzhiyeva and Others v. Belgium ${ }^{61}$ involved a Russian mother and her four children. In October 2006, they fled from Grozny (Chechnya) and subsequently arrived in Belgium, where they sought asylum. In consideration of the fact that she and her children had stayed in Poland at some point in their lives, the Polish authorities relied on the "Dublin II" Regulation and agreed to take charge of them. Nevertheless, the Belgian authorities did not grant them the requisite asylum or permission to stay in the country, making a subsequent order for them to leave therein. In January 2007, they were placed in a

${ }^{57} \mathrm{UN}$ Human Rights Council (2008). Report of the Working Group on Arbitrary Detention. UN Doc A/HRC/7/4, para 67; See generally Chetail, Vincent (2014). "The Transnational Movement of Persons under General International Law-Mapping the Customary Law Foundations of International Migration Law". In: Research Handbook on International Law and Migration, edited by Chetail, $\mathrm{V}$ and Bauloz, C (eds). Cheltenham, UK: Edward Elgar Publishing, 1-72.

${ }^{58}$ Chetail, ibid, 50.

${ }^{59} \mathrm{R}$ v. Secretary of State for the Home Department, ex parte Saadi and Others [2002] 4 All ER 785 (HL), 794-795 (per Lord Slynn of Hadley); Chetail (n 57) 50.

${ }^{60}$ ECtHR, Saadi v. The United Kingdom (Judgment; Grand Chamber) (2008) Appl. No. 13229/03, para. 64; Chetail, ibid, 50-51.

${ }^{61}$ ECtHR Application No 41442/07 (last checked 23 February 2020)

http://www.asylumlawdatabase.eu/en/content/ecthr-muskhadzhiyeva-and-others-v-belgium-applica tion-no-4144207. 
closed transit centre run by the Aliens Office near Brussels airport, where aliens (single adults or families) were held pending their removal from the country ${ }^{62}$ (European Court of Human Rights Factsheet, 2018). Considering the relatively young age of the children, the duration of their detention and their state of health as attested to by medical certificates during their detention, the European Court of Human Rights (ECtHR) found that the conditions under which the children had been held in the closed transit centre had attained the minimum level of severity required to constitute a violation of Article 3 (prohibition of inhuman or degrading treatment) of the ECtHR. In particular, the court emphasised that the extreme vulnerability of a child was a paramount consideration which takes precedence over the status of mother and/or child as an illegal alien. Although the four children had not been separated from their mother in the present case, this was not sufficient to exempt the authorities from their legal obligation to protect the children. As such, the duration of time within which the children were held in the closed centre (one month) and the conditions of the centre not being suitable to house children for that duration was considered and confirmed by several reports before the Court.

The ECtHR took a similar stance in Kanagaratnam v. Belgium ${ }^{63}$. In this case, detention of the mother and three children (who were relatively older than the children in the Muskhadzhiyeva case) was for almost four months in a closed transit centre pending their removal from Belgium. The Court held that there had been a violation of Article 3 (prohibition of inhuman or degrading treatment) of the Convention on the Rights of the Child with regards to the children, citing the comparable circumstances of this case with the Muskhadzhiyeva case above. The Court considered the vulnerability of the children, psychological trauma experienced by the children who must have been traumatised before their arrival in Belgium as a result of circumstances relating to the civil war in their home country Sri Lanka and other circumstances which were acknowledged by the Belgian authorities before granting the family refugee status. The court noted that this vulnerability had increased by such placement in the closed transit centre for 4 months and as such, posed a risk to their mental health and development $^{64}$ (European Court of Human Rights Factsheet, 2018).

In Popov v. France ${ }^{65}$, France rejected the asylum applications for asylum and for residence permits of a married Kazakhstan couple and their two children. In August 2007, the family was arrested at their home, taken into police custody and transferred the following day to Charles-de-Gaulle airport, France to be flown back to Kazakhstan. Due to a flight cancellation, the family were taken to the Rouen-Oissel administrative detention centre, which was authorised to ac${ }^{62}$ European Court of Human Rights (2018). Factsheet-Accompanied migrant minors in detention. 1 (last checked 23 February 2020) https://www.refworld.org/pdfid/5a5f7ee44.pdf. ${ }^{63}$ ECtHR Application No 15297/09, 13 March 2012.

${ }^{64}$ ECtHR Factsheet, ibid, 1-2.

${ }^{65}$ ECtHR, Application Nos 39472/07 and 37474/07 (last checked 23 February 2020) http://www.asylumlawdatabase.eu/en/content/ecthr-popov-v-france-application-nos-3947207-and-3 $\underline{947407}$ 
commodate families and were placed there for two weeks. In a similar manner as what obtained in the above two cases, ECtHR held that there had been a violation of Article 3 (prohibition of inhuman or degrading treatment) of the Convention with regards to the detention conditions of the children, especially as the couple's children were aged three years and 5 months old. The Council of Europe Commissioner for Human Rights had reported that the nature of the centres proved unconducive for children, including living arrangements, and perceived stress, insecurity, and hostile atmosphere. In contradiction with international child protection principles according to which the authorities must do everything in their power to avoid detaining children for lengthy periods. The court agreed that a two weeks' detention period was not particularly excessive but could appear to be so when considering the ages of the children who were not used to living within such distressing conditions. However, the Court found that France was not in violation of Article 3 of the Convention with regards to detention conditions of the parents, as the parents had not been separated from the children within the two-period or at any time ${ }^{66}$ (European Court of Human Rights, 2018).

These pronouncements by the ECtHR ought to serve as a deterrent to States to exercise their sovereign right to detention of irregular migrant children with due care and caution in view of existing international human rights instruments which cater to the rights of irregular migrant children. Nevertheless, there still remains a blatant refusal by states to adhere to these international standards, resulting in a gulf between these proclaimed standards and the application of States legislation ${ }^{67}$ to irregular migrant children. What then is the way forward?

\section{Towards a Global Harmonised Migration Governance Regime for Irregular Migrant Children: Recommendations}

The global migration regime comprises a complex, and often fragmented, institutional and legal architecture for international cooperation and dialogue on migration issues ${ }^{68}$ (Migration, Human Rights \& Governance, 2015). The ongoing tension between rights and reality echoes the schizophrenic nature of an international legal system which is grounded on two contradictory driving forces ${ }^{69}$ (Chetail, 2013). On the one hand, due respect of non-discrimination is primarily ensured by a decentralised scheme entrusted to nation states. On the other hand, "the universal respect for, and observance of human rights and fundamental freedoms for all without distinction" is acknowledged as one of the founding principles of the international legal order instituted by the UN Charter ${ }^{70}$ (Chetail, 2013). Consequently, the indifference of the law towards undocumented mi${ }^{66}$ ECtHR Factsheet (n 62) 2-3.

${ }^{67}$ Cholewinski, R. (2007-2008) The Human and Labor Rights of Migrants: Visions of Equality. Georgetown Immigration Law Journal, 22, 195.

${ }^{68}$ Migration, Human Rights and Governance (n 15), 140.

${ }^{69}$ Chetail (n 18) 254.

${ }^{70}$ Art 55 (C), UN Charter; Chetail (n 18) 254. 
grants and to their legal exclusion from rights, places them in a "legal limbo". The normalisation in everyday life of such legal exclusion [facilitated by detention and ill-treatment of migrant children] leads to the endorsement and facilitation of the social, economic and political segregation of undocumented migrants by the law. It allows for the construction of a group of 'second-class' persons and a "society of dismissal"71 (De Lucas, 2013).

This article posits that the universality of protection of human rights of children afforded by the Convention of the Rights of the Child and other international human rights instrument must continue to be upheld by controlled migration governance, which includes coordination and cooperation among states that have already established alternatives to detention of irregular migrant children. Currently, the existing situation between States who still practice detention of migrant children and the international community appears to be that of "Russian Roulette" - a show of power by States that they have the right to protect their territories from invasion by teeming irregular migrants. To curtail this show of power, the United Nations, through various resolutions and strategic documents, continues to promote and protect the human rights of migrants. In 2017, the UN noted that "unaccompanied migrant children and families with children must never be detained for reasons relating to their administrative immigration status. Consequently, both unaccompanied migrant children and families with children should always be provided with alternatives to detention ... [such as] ... payment of bonds or bail or the provision of a surety or guarantor, reporting requirements, case management or supervised release, designated residence ... electronic monitoring [etc]"72 (United Nations General Assembly Report, 2017). These alternatives to detention will help to ensure a more humane treatment of irregular migrant children and their families rather than physical detention in inadequate, unsafe detention centres.

Currently, a transnational network of scholars, practitioners, expert and students have developed the International Migrants Bills of Rights (IMBR), a soft-law framework which innovatively posits a legal definition of international migrants and fames the rights and needs of vulnerable migrants-including children ${ }^{73}$ (Kysel, 2016). Thus, this article recommends that concerted efforts between civil society organisations in Europe and Australia, drafters of the IMBR and the International Detention Coalition (IDC) towards developing, investing and implementing these workable alternatives to detention centres will greatly improve States' orientation towards the treatment of irregular migrant children. This collaboration will ensure that the human rights of children are continually upheld in migration law and policy. Whatever action is further developed and/or proposed by the international community within the next decade

${ }^{71}$ De Lucas, J. Immigracion e integracion en la UE: dos retos para el s, XXI, Eurobask, 11-13 in Estrada-Tanck (n 9) 168.

${ }^{72}$ United Nations General Assembly A/72/173 (2017). Report of the Special Rapporteur on the human rights of migrants. 19 July, Paras $60 \& 61$.

${ }^{73}$ Kysel (n 17) 32. 
regarding protecting the human rights of irregular migrant children, it is imperative that the most appropriate solution which is based on the children's best interests and well-being, must be placed ahead of a States' externalization policies on migration, to ensure an effective harmonised governance framework for irregular migrant children.

\section{Conclusion}

Border controls and the attendant detention mechanisms utilised by States are an ever-present reality for the international community and for irregular migrants. Although international law cannot completely curtail the sovereign right of States to control persons who seek to enter and remain within their territories, international human rights law requires that arrangements for detention in these States should be-at the very least-humane and without prolonged institutionalization of irregular migrants and their children. Until these considerations are carefully examined by destination and transit states and alternative measures as proffered above are implemented, the issues of human rights violation and attempts at judicial interpretation of same will remain rampant in States.

\section{Conflicts of Interest}

The author declares no conflicts of interest regarding the publication of this paper.

\section{References}

Bhabha, J. (2009). Arendt's Children: Do Today's Migrant Children Have a Right to Have Rights? Human Rights Quarterly, 31, 410. https://doi.org/10.1353/hrq.0.0072

Chetail, V. (2013). The Human Rights of Migrants in General International Law: From Minimum Standards to Fundamental Rights. Georgetown Immigration Law Journal, $28,231-232$.

Cholewinski, R. (2007-2008). The Human and Labor Rights of Migrants: Visions of Equality. Georgetown Immigration Law Journal, 22, 195.

Estrada-Tanck, D. (2013). Human Security and the Human Rights of Undocumented Migrants: Systemic Vulnerabilities and Obligations of Protection. European Journal of Social Security, 15, 155. https://doi.org/10.1177/138826271301500203

Fraser, J., \& Konigs, T. (2012). Towards the Benefit of All: Protecting Migrants' Rights in a Globalised World. Merkorious-Utrecht Journal of International and European Law, 28, 55-66. https://utrechtjournal.org/articles/10.5334/ujiel.bi/galley/35/download/ https://doi.org/10.5334/ujiel.bi

Frelick, B., Kysel, M. I., \& Podkul, J. (2016). The Impact of Externalization of Migration Controls on the Rights of Asylum Seekers and Other Migrants. Journal on Migration and Human Security, 4, 190-197. https://doi.org/10.14240/jmhs.v4i4.68

Goodwin-Gill, G. (1989). International Law and Human Rights: Trends Concerning International Migrants and Refugees. International Migration Review, 23, 526. https://doi.org/10.2307/2546427

Kysel, M. I. (2016). Promoting the Recognition and Protection of the Rights of All Migrants Using a Soft-Law International Migrants Bill of Rights. Journal of Migration and 
Human Security, 4, 29-31. https://doi.org/10.14240/jmhs.v4i2.60

Mejivar, C. (2014). Immigration Law beyond Borders: Externalizing and Internalizing Border Controls in an Era of Securitization. Annual Review of Law and Social Science, 10, 353-361. https://doi.org/10.1146/annurev-lawsocsci-110413-030842

Menjivar, C. (2006). Liminal Legality: Salvadoran and Guatemalan Immigrants' Lives in the United States. American Journal of Sociology, 111, 999-103.

https://doi.org/10.1086/499509

Noll, G. (2010). Why Human Rights Fail to Protect Undocumented Migrants. European Journal of Migration and Law, 12, 241, 249-254. https://doi.org/10.1163/157181610X496894

Sampson, R., \& Mitchell, G. (2013). Global Trends in Immigration Detention and Alternatives to Detention: Practical, Political and Symbolic Rationales. Journal on Migration and Human Security, 3, 35. https://doi.org/10.1177/233150241300100302

Van Waas, L. (2007). The Children of Irregular Migrants: A Stateless Generation. Netherlands Quarterly of Human Rights, 25, 437-458.

https://doi.org/10.1177/016934410702500303 


\section{Appendix}

\section{Report}

(2012). PICUM Submission to the OHCHR Special Rapporteur on Migrants, Thematic Report on Detention.

(2014). The Forgotten Children-National Inquiry into Children in Immigration Detention (p. 24). Sydney: Australian Human Rights Commission.

Amnesty International (2017). The Human Rights Risks of External Migration Policies (p. 5). London: Amnesty International Ltd.

European Union Agency for Fundamental Rights Report (2017). European Legal and Policy Framework on Immigration Detention of Children (p. 44).

\section{Book}

Cassese, A. (2001). International Law (p. 97). Oxford: Oxford University Press.

Chetail, V and Bauloz, C (eds) (2014). Research Handbook on International Law and Migration (pp. 1-72). Cheltenham, UK: Edward Elgar Publishing.

Johnson, N. (2015). Deterrence, Detention and Deportation: Child Migrants in the United States \& the European Union. Washington DC: Heinrich Boll Stiftung. III.

Mossou, S. (2017). Child Immigration Detention in Europe-Human Rights Programme Report (p. 6). Belgium: Quaker Council for European Affairs.

\section{Internet}

(2014). The Hidden Face of Immigration Detention Camps in Europe. http://www.migreurop.org/article2537.html?lang=fr

(2015). Migration, Human Rights and Governance-Handbook for Parliamentarians No. 24. Inter-Parliamentary Union/International Labour Organization/The United Nations Office of the High Commissioner for Human Rights, 113. https://www.refworld.org/docid/57b6e1697.html

Coordination et Initiatives pour réfugiés et étrangers: Lancement de la campagne 'on n'enferme pas des enfants. Point.

https://www.cire.be/presse/communiques-de-presse/lancement-de-la-campagne-on-nenferme-pas-un-enfant-point-communique-de-presse-14-juin-2016

ECtHR Application No. 41442/07.

http://www.asylumlawdatabase.eu/en/content/ecthr-muskhadzhiyeva-and-others-v-bel gium-application-no-4144207

ECtHR, Application Nos 39472/07 and 37474/07.

http://www.asylumlawdatabase.eu/en/content/ecthr-popov-v-france-application-nos-3 947207-and-3947407

European Court of Human Rights (2018). Factsheet-Accompanied Migrant Minors in Detention. http://www.refworld.org/pdfid/5a5f7ee44.pdff

Human Rights Watch (2016). Papua New Guinea: Address Abuses at UN Review: Make Good on Commitment to Close Manus Detention Centre. New York: Human Rights Watch.

https://webcache.googleusercontent.com/search?q=cache:AYNPj36NpxsJ:https://www. hrw.org/news/2016/05/04/papua-new-guinea-address-abuses-un-review $+\& c d=1 \& h l=e$ $\mathrm{n} \& \mathrm{ct}=\mathrm{clnk} \& \mathrm{gl}=\mathrm{ng}$

Parliamentary Assembly (2014). The Alternatives to Immigration Detention of Children. Doc. 13597. 
http://assembly.coe.int/nw/xml/XRef/Xref-XML2HTML-en.asp?fileid=21130\&lang=en

The Alternatives to Immigration Detention of Children.

https://www.refworld.org/pdfid/547c7c834.pdf

United Nations Human Rights. Migration and Human Rights-Improving Governance of International Migration (pp. 8, 16).

https://www.ohchr.org/Documents/Issues/Migration/MigrationHR_improvingHR_Re port.pdf 